\title{
Impact of Temperature, Osmotic Potential, and Osmoregulant on the Growth of Three Ectotrophic Root-Infecting Fungi of Kentucky Bluegrass
}

\author{
Karen A. Plumley, Ann B. Gould, and Bruce B. Clarke, Department of Plant Pathology, Rutgers University, New \\ Brunswick, NJ 08903
}

\begin{abstract}
Plumley, K. A., Gould, A. B., and Clarke, B. B. 1997. Impact of temperature, osmotic potential, and osmoregulant on the growth of three ectotrophic root-infecting fungi of Kentucky bluegrass. Plant Dis. 81:873-879.

Two isolates each of Magnaporthe poae, Gaeumannomyces incrustans, and Leptosphaeria korrae were grown at $25^{\circ} \mathrm{C}$ in liquid shake culture in minimal salts medium $(-0.12 \mathrm{MPa})$ or minimal salts medium adjusted to $-0.5 \mathrm{MPa}$ with $\mathrm{KCl}, \mathrm{MgCl}_{2}$, or polyethylene glycol (PEG). Fungal dry weight of all three species was greater in minimal salts medium amended to -0.5 $\mathrm{MPa}$ with $\mathrm{MgCl}_{2}$ than in nonamended medium, and dry weight in medium amended with PEG was not different from dry weights in nonamended medium or medium amended with $\mathrm{KCl}$. Fungi were incubated at varying temperatures on a minimal salts solid-agar medium $(-0.12 \mathrm{MPa})$ adjusted to osmotic potentials ranging from -0.5 to $-5.0 \mathrm{MPa}$ with $\mathrm{KCl}$ or $\mathrm{MgCl}_{2}$. Optimum growth of M. poae, G. incrustans, and L. korrae on nonamended medium occurred at 30, 30, and $25^{\circ} \mathrm{C}$, respectively. At optimum temperatures for each species, fungal growth was greatest at the higher osmotic potentials tested $(-0.5$ to $-1.0 \mathrm{MPa})$ and decreased in a linear manner as osmotic potential decreased. In most cases, growth was detected at the lowest osmotic potential measured $(-5.0 \mathrm{MPa})$. The relationship of fungal growth to osmotic potential depended on both temperature and osmoregulant. At temperatures optimal or nearly optimal for fungal development, the growth of all three fungi declined more rapidly with decreasing osmotic potential when grown on medium amended with $\mathrm{MgCl}_{2}$ than on medium amended with $\mathrm{KCl}$. At the highest temperature evaluated for growth of $M$. poae and $L$. korrae $\left(35\right.$ and $30^{\circ} \mathrm{C}$, respectively), growth on medium amended with $\mathrm{KCl}$ was curvilinear and peaked at osmotic potentials of -2.5 to $-3.0 \mathrm{MPa}$. Furthermore, between osmotic potentials of -2.0 and $-5.0 \mathrm{MPa}$, M. poae grew best at $35^{\circ} \mathrm{C}$. When maintained on nonamended minimal salts medium $(-0.12 \mathrm{MPa})$ in liquid culture at $25^{\circ} \mathrm{C}$ or on nonamended solid-agar medium at temperatures optimal for growth, M. poae grew at a faster daily rate than $L$. korrae.
\end{abstract}

Patch diseases, caused by ectotrophic rootinfecting fungi, represent a newly recognized, destructive group of turfgrass diseases. Since the late 1970 s, there has been a rapid expansion of knowledge pertaining to this group of fungi. As a result, several species of ectotrophic fungi have been implicated in patch disease development (13). The influence of environmental factors, particularly soil moisture, on disease development is still poorly understood, however.

Leptosphaeria korrae J.C. Walker \& A.M. $\mathrm{Sm}$. is the causal agent of necrotic ring spot, a disease of Poa and Festuca species (19, 26). This pathogen also is associated with spring dead spot, a patch disease of bermudagrass (Cynodon dactylon) (13). L. korrae infects turfgrass roots and crowns during cool, wet weather (20). Magnaporthe poae Landschoot \& Jackson, originally identified as Phialophora graminicola (Deacon) J. Walker (19), is the causal agent of sum-

Corresponding author: A. B. Gould E-mail: GOULD@AESOP.RUTGERS.EDU

Accepted for publication 3 April 1997.

Publication no. D-1997-0520-04R

(C) 1997 The American Phytopathological Society incrustans in vitro were investigated both independently and interactively, using $\mathrm{KCl}$ as an osmoregulant (9). Both temperature and osmotic potential regulated the growth of these fungi. At 25 and $30^{\circ} \mathrm{C}$, growth of $M$. poae was greatest at $-0.12 \mathrm{MPa}$ and decreased as osmotic potential was reduced. At $35^{\circ} \mathrm{C}$, isolates of $M$. poae produced maximal growth at lower osmotic potentials $(-1.03$ to $-1.49 \mathrm{MPa})$. The growth response of $M$. poae to various osmotic potentials was temperature dependent. This type of study has not been conducted for $L$. korrae. Because Kackley et al. (9) used only one osmoticum $(\mathrm{KCl})$ to adjust osmotic potential, the possible effect of osmoregulant on fungal growth was not addressed. Brownell and Schneider (3) demonstrated that osmoregulant affected the growth of Fusarium oxysporum on minimal nutrient medium amended with either $\mathrm{MgCl}_{2}$ or $\mathrm{KCl}$. If this phenomenon were true for ectotrophic fungi such as $M$. poae, G. incrustans, and L. korrae, then their growth on an amended basal medium could vary considerably at different osmotic potentials and temperatures.

The objectives of this study were to evaluate the effects of temperature and osmotic potential on the growth of $M$. poae, $L$. korrae, and G. incrustans in vitro. These parameters were examined alone and interactively to determine the optimum conditions required for growth of each fungus. Because solutes in growth medium may influence fungal growth through nutritional or fungitoxic means, three solutes were used as osmoregulants to determine the impact of osmotic potential on fungal growth.

\section{MATERIALS AND METHODS}

Fungal isolates. Two isolates each of $M$. poae (American Type Culture Collection [ATCC], Rockville, MD, 64411 and 64412), G. incrustans (ATCC 64416 and 64417), and L. korrae (PJL1 and PJL2) were maintained on half-strength PDA (Difco Laboratories, Detroit) at $25^{\circ} \mathrm{C}$ and subcultured regularly. Both cultures of $L$. korrae were isolated by P. J. Landschoot (The Pennsylvania State University, University Park) from Kentucky bluegrass exhibiting symptoms of necrotic ring spot.

Impact of osmoregulant on fungal growth in liquid culture. Osmoregulant treatments were prepared by amending a minimal salts medium with a low organic nutrient content and a baseline osmotic potential of $-0.12 \mathrm{MPa}$ (22) to $-0.5 \mathrm{MPa}$, us- 
ing $\mathrm{KCl}, \mathrm{MgCl}_{2}$, or polyethylene glycol (PEG). Calibrated Peltier (Logan, UT) thermocouple psychrometers were utilized to determine the osmotic potential (2) of the nonamended and amended minimal salts media.

Each fungal isolate described above was grown for 4 days at $25^{\circ} \mathrm{C}$ on PDA plates overlaid with sterile cellophane. One 6-mm

Table 1. Summary of combined analysis of variance for growth (fungal dry weight) of Magnaporthe poae, Gaeumannomyces incrustans, and Leptosphaeria korrae at $25^{\circ} \mathrm{C}$ in liquid shake culture containing minimal salts medium $(-0.12 \mathrm{MPa})$ or minimal salts medium adjusted to $-0.5 \mathrm{MPa}$ with $\mathrm{MgCl}_{2}, \mathrm{KCl}$, or polyethylene glycol

\begin{tabular}{|c|c|c|c|}
\hline $\begin{array}{l}\text { Source } \\
\text { of variation }\end{array}$ & df & $\mathbf{M S}^{\mathbf{y}}$ & $F^{\mathbf{z}}$ \\
\hline $\begin{array}{l}\text { Experiment } \\
\text { (EXP) }\end{array}$ & 1 & 3.1 & 3.3 \\
\hline Fungus (F) & 2 & 131.0 & $140.3 * * * *$ \\
\hline $\mathrm{EXP} \times \mathrm{F}$ & 2 & 0.1 & 0.1 \\
\hline $\begin{array}{l}\text { Fungal isolate } \\
\quad(\mathrm{EXP} \times \mathrm{F})\end{array}$ & 6 & 5.0 & $5.3 * * *$ \\
\hline $\begin{array}{l}\text { Osmoregulant } \\
\text { (OS) }\end{array}$ & 3 & 19.1 & $20.5 * * * * *$ \\
\hline $\mathrm{OS} \times \mathrm{EXP}$ & 3 & 0.1 & 0.1 \\
\hline $\mathrm{OS} \times \mathrm{F}$ & 6 & 1.3 & 1.4 \\
\hline $\mathrm{EXP} \times \mathrm{F} \times \mathrm{OS}$ & 6 & 2.2 & $2.4^{*}$ \\
\hline Error & 115 & 0.9 & \\
\hline
\end{tabular}

${ }^{\mathrm{y}}$ Mean square.

$\mathrm{z} * * * *=$ significant at $P=0.0001 ; * * *=$ significant at $P=0.001$; and $*=$ significant at $P=$ 0.05 .

Table 2. Summary of combined analysis of variance for growth (mean colony diameter) of Magnaporthe poae, Gaeumannomyces incrustans, and Leptosphaeria korrae on minimal salts agar medium adjusted to osmotic potentials ranging from -0.5 to $-5.0 \mathrm{MPa}$ with $\mathrm{MgCl}_{2}$ or $\mathrm{KCl}$ at $20,25,30$, and $35^{\circ} \mathrm{C}$ (M. poae and $G$. incrustans) or $15,20,25$, and $30^{\circ} \mathrm{C}$ (L. korrae)

\begin{tabular}{lrrr}
\hline $\begin{array}{l}\text { Source } \\
\text { of variation }\end{array}$ & \multicolumn{1}{c}{ df } & \multicolumn{1}{c}{ MS } & \multicolumn{1}{c}{$\boldsymbol{F}^{\mathbf{z}}$} \\
\hline Fungus (F) & 2 & 4,046 & $52.7^{* * * * *}$ \\
Experiment & & & \\
$\quad$ EXP) & 1 & 212 & 2.8 \\
F X EXP & 2 & 146 & 1.9 \\
Fungal isolate & & & \\
$\quad($ EXP $\times$ F) & 6 & 4,340 & $56.6^{* * * *}$ \\
Osmoticum & & & \\
$\quad(\mathrm{OS})$ & 1 & 51,036 & $664.9^{* * * *}$ \\
OS $\times$ EXP & 1 & 3,759 & $50.0^{* * * *}$ \\
OS $\times \mathrm{F}$ & 2 & 6 & 0.1 \\
Temperature (T) & 4 & 16,651 & $216.9^{* * * *}$ \\
T $\times \mathrm{F}$ & 8 & 16,088 & $209.6^{* * * *}$ \\
T $\times$ EXP & 4 & 632 & $8.2^{* * * *}$ \\
T $\times$ OS & 4 & 7,085 & $92.3^{* * * *}$ \\
Osmotic & & & \\
$\quad$ potential (OP) & 5 & 58,041 & $756.2^{* * * *}$ \\
OP $\times \mathrm{F}$ & 10 & 2471 & $32.2^{* * * *}$ \\
OP $\times$ EXP & 5 & 287 & $3.7^{* * *}$ \\
OP $\times$ OS & 5 & 1,592 & $20.8^{* * * *}$ \\
OP $\times$ T & 20 & 3,867 & $50.4^{* * * *}$ \\
Error & 1,946 & 77 & \\
\hline
\end{tabular}

y Mean square.
$\mathrm{z} * * * *$ significant at $P<0.0001$; and $* *=$ significant at $P<0.01$. disk was aseptically cut from the margin of each cellophane colony with a cork borer and ground with a sterile mortar and pestle in $1 \mathrm{ml}$ of amended or nonamended minimal salts medium. The fungal slurry was added to $3 \mathrm{ml}$ of the same medium in a sterile $15-\mathrm{ml}$ test tube and incubated at $25^{\circ} \mathrm{C}$ on a shaker $(180 \mathrm{rpm})$. After 8 (M. poae and G. incrustans) or 10 (L. korrae) days, fungal dry weight was determined by placing a preweighed filter-paper disk in a Buchner funnel and suctioning off the liquid medium. The disks were dried for $48 \mathrm{~h}$ at room temperature and reweighed. Each osmoregulant-fungal isolate combination was replicated four times, and the entire experiment was repeated.

Differences in fungal dry weight were analyzed as a factorial design by analysis of variance (ANOVA) with experiment, osmoregulant, fungus, and fungal isolate as main effects (Table 1). The impact of osmoregulant on the dry weight of each fungal isolate was assessed by one-way ANOVA, and the least-squares means separation procedure was used to analyze differences in treatment means. SAS (SAS Institute, Inc., Cary, NC) was used for all statistical computations.

Impact of temperature and osmotic potential on fungal growth. Each fungal isolate was grown for 5 days at $25^{\circ} \mathrm{C}$ on minimal salts $(-0.12 \mathrm{MPa})$ solid-agar medium. Fungal plugs $(6 \mathrm{~mm})$ were removed with a sterile cork borer from colony margins and placed in the center of petri dishes containing $20 \mathrm{ml}$ of nonamended minimal salts agar medium or on the same medium adjusted to different osmotic potentials $(-0.5$, $-1.0,-2.0,-3.0,-4.0$, or $-5.0 \mathrm{MPa}$ ) with $\mathrm{KCl}$ or $\mathrm{MgCl}_{2}$. Four replicate petri dishes for each isolate-osmoregulant-osmotic potential combination were prepared, and all plates were placed in a sealed plastic bag and incubated in an inverted position in the dark at one of four temperatures. M. poae and $G$. incrustans were incubated at 20,25, 30 , and $35^{\circ} \mathrm{C}$. L. korrae was incubated at $15,20,25$, and $30^{\circ} \mathrm{C}$ due to its lower temperature requirement for optimum growth (23). To assess fungal growth, two perpendicular measurements of colony diameter were recorded and averaged every $48 \mathrm{~h}$.
Measurements continued for each species until mycelium in the treatment with the fastest growth had reached the margin of the plate. The experiment was repeated.

Differences in mean colony diameter after 6 (M. poae and G. incrustans) or 14 ( $L$. korrae) days were analyzed as a factorial design by ANOVA, with experiment (trial), fungus, fungal isolate, osmoregulant, temperature, and osmotic potential as main effects (Table 2). The relationship between osmotic potential (independent variable) and fungal growth (dependent variable) for each osmoregulant at each temperature was quantified by linear regression analysis. For each fungus, slopes and intercepts of regression lines between isolates, osmoregulants, and temperatures were compared by analysis of the heterogeneity of slopes.

\section{RESULTS}

Effect of osmoregulant on fungal growth in liquid culture. Because fungal dry weight did not differ between experiments $(P>$ 0.05 ) (Table 1), data from both trials were analyzed collectively. Dry weight of $M$. poae, L. korrae, and G. incrustans ATCC 64417 was greater in minimal salts medium amended to $-0.5 \mathrm{MPa}$ with $\mathrm{MgCl}_{2}$ than in nonamended medium or medium amended with PEG (Table 3). Differences in fungal growth among osmoregulant treatments for G. incrustans ATCC 64416 were not significant. Growth of $M$. poae on medium amended with $\mathrm{KCl}$ did not differ from growth on medium amended with $\mathrm{MgCl}_{2}$; the opposite was true for $L$. korrae and $G$. incrustans ATCC 64417. For all species, fungal dry weights in medium amended with PEG was not different from dry weights in nonamended medium or medium amended with $\mathrm{KCl}$. For this reason, and because agar fortified with PEG does not solidify (3), PEG was deleted from further consideration. In liquid culture at $25^{\circ} \mathrm{C}, M$. poae grew at a faster daily rate than $L$. korrae and $G$. incrustans $(0.98,0.52$, and 0.56 $\mathrm{mg} /$ day, respectively) (Table 4).

Relationship of temperature, osmotic potential, and osmoregulant to fungal growth on agar medium. Mean colony diameter was not different between experiments $(P=0.10)$ (Table 2$)$, so data from

Table 3. Dry weight of Magnaporthe poae, Gaeumannomyces incrustans, and Leptosphaeria korrae isolates grown at $25^{\circ} \mathrm{C}$ in liquid shake culture containing minimal salts medium $(-0.12 \mathrm{MPa})$ or minimal salts medium adjusted to $-0.5 \mathrm{MPa}$ with $\mathrm{MgCl}_{2}, \mathrm{KCl}$, or polyethylene glycol (PEG)

\begin{tabular}{|c|c|c|c|c|c|c|}
\hline \multirow[b]{2}{*}{ Osmoregulant } & \multicolumn{2}{|c|}{ M. poae ${ }^{\mathrm{y}}$} & \multicolumn{2}{|c|}{ G. incrustans ${ }^{\mathrm{y}}$} & \multicolumn{2}{|c|}{ L. korrae $^{\mathrm{y}}$} \\
\hline & $\begin{array}{c}\text { ATCC } \\
64411 \\
\end{array}$ & $\begin{array}{l}\text { ATCC } \\
64412 \\
\end{array}$ & $\begin{array}{l}\text { ATCC } \\
64416 \\
\end{array}$ & $\begin{array}{l}\text { ATCC } \\
64417 \\
\end{array}$ & PJL1 & PJL2 \\
\hline $\mathrm{MgCl}_{2}$ & $8.45 \mathrm{a}$ & $9.84 \mathrm{a}$ & $7.60 \mathrm{a}$ & $6.88 \mathrm{a}$ & $5.90 \mathrm{a}$ & $6.68 \mathrm{a}$ \\
\hline $\mathrm{KCl}$ & $7.75 \mathrm{ab}$ & $8.65 \mathrm{ab}$ & $7.35 \mathrm{a}$ & $4.97 \mathrm{~b}$ & $5.27 \mathrm{~b}$ & $5.17 \mathrm{~b}$ \\
\hline PEG & $7.15 \mathrm{~b}$ & $8.31 \mathrm{~b}$ & $5.47 \mathrm{a}$ & $4.69 \mathrm{~b}$ & $4.90 \mathrm{~b}$ & $5.04 \mathrm{~b}$ \\
\hline $\begin{array}{l}\text { Nonamended } \\
\text { medium }^{\mathrm{z}}\end{array}$ & $7.59 \mathrm{~b}$ & $8.04 \mathrm{~b}$ & $5.25 \mathrm{a}$ & $4.23 \mathrm{~b}$ & $5.07 \mathrm{~b}$ & $5.34 \mathrm{~b}$ \\
\hline
\end{tabular}

${ }^{y}$ Fungal dry weights (milligrams) were determined for each osmoregulant treatment 8 (M. poae and G. incrustans) or 10 (L. korrae) days after inoculation. Means within a column followed by the same letter are not significantly different $(P<0.05$, least squares means).

z $-0.12 \mathrm{MPa}$. 
both trials were combined prior to further analysis. After 6 days, the temperature that was optimal for growth of $M$. poae and $G$. incrustans on nonamended minimal salts agar medium $(-0.12 \mathrm{MPa})$ was $30^{\circ} \mathrm{C}$ (84 and $69 \mathrm{~mm}$, respectively) (Fig. 1). For both fungi, mean colony diameter at $35^{\circ} \mathrm{C}$ was reduced by approximately $80 \%$ and was intermediate at 20 and $25^{\circ} \mathrm{C}$. Alternatively, growth of $L$. korrae after 14 days was greatest at $25^{\circ} \mathrm{C}$ and poorest at $30^{\circ} \mathrm{C}(63$ and $11 \mathrm{~mm}$, respectively) (Fig. 1). When maintained on minimal salts agar medium at an optimal temperature for growth, $M$. poae grew at a faster daily rate than the other fungi evaluated (Table 4).

Regardless of incubation temperature, growth of all fungal species on minimal salts agar medium amended with either $\mathrm{KCl}$ or $\mathrm{MgCl}_{2}$ was affected by changes in osmotic potential in a linear or curvilinear manner (Figs. 2 through 4). In most cases, mean colony diameter was greatest between -0.5 and $-1.0 \mathrm{MPa}$ and decreased as osmotic potential decreased. At very low osmotic potentials ( -4.0 to $-5.0 \mathrm{MPa}$ ), fungal growth at all temperatures was minimal or nonexistent.
The relationship of fungal growth to osmotic potential depended on temperature and osmoregulant (Table 2; Figs. 2 through 4). Within each isolate of $G$. incrustans and $L$. korrae grown on medium amended with $\mathrm{KCl}$ or $\mathrm{MgCl}_{2}$, the y-intercept of regression lines differed with varying temperature $(P<0.001)$ based on analysis of the heterogeneity of slopes. Alternatively, $y-$ intercepts did not differ for the two $M$. poae isolates grown at 25 or $30^{\circ} \mathrm{C}$ on medium amended with $\mathrm{MgCl}_{2}(P>0.2)$, nor did they differ for $M$. poae ATCC 64411 grown at 20 or $35^{\circ} \mathrm{C}$ on medium amended with $\mathrm{KCl}(P=0.4)$. For both isolates of $M$. poae, mean colony diameter declined more rapidly with decreasing osmotic potential at 20 and $25^{\circ} \mathrm{C}$ when grown on medium amended with $\mathrm{MgCl}_{2}$ than when grown on medium amended with $\mathrm{KCl}(P<0.04)$ (Fig. 2). This same trend was observed at $30^{\circ} \mathrm{C}$ for $G$. incrustans ATCC $64416(P<$ 0.001 ) (Fig. 3); at 20,25 , and $30^{\circ} \mathrm{C}$ for $G$. incrustans ATCC $64417(P<0.05)$; at $20^{\circ} \mathrm{C}$ for L. korrae PJL1 ( $P<0.001)$ (Fig. 4); and at 15,20 , and $25^{\circ} \mathrm{C}$ for L. korrae PJL2 $(P<0.05)$.

When maintained on medium amended with $\mathrm{KCl}$, maximum growth of $M$. poae

Table 4. Average growth rates ${ }^{\mathrm{y}}$ of Magnaporthe poae, Gaeumannomyces incrustans, and Leptosphaeria korrae on nonamended minimal salts medium $(-0.12 \mathrm{MPa})$ in liquid shake culture at $25^{\circ} \mathrm{C}$ and on nonamended minimal salts medium $(-0.12 \mathrm{MPa})$ at temperatures optimum for growth

\begin{tabular}{lccc}
\hline & & \multicolumn{2}{c}{ Minimal salts medium } \\
\cline { 3 - 4 } Fungal species & $\begin{array}{c}\text { Liquid culture } \\
(\mathbf{m g} / \mathbf{d a y})^{\mathbf{z}}\end{array}$ & $\begin{array}{c}\text { Optimum } \\
\text { temperature }\left({ }^{\circ} \mathbf{C}\right)\end{array}$ & $\begin{array}{c}\text { Radial growth } \\
(\mathbf{m m} / \mathbf{d a y})^{\mathbf{z}}\end{array}$ \\
\hline M. poae & $0.98 \mathrm{a}$ & 30 & $7.00 \mathrm{a}$ \\
G. incrustans & $0.56 \mathrm{~b}$ & 30 & $5.74 \mathrm{~b}$ \\
L. korrae & $0.52 \mathrm{~b}$ & 25 & $2.24 \mathrm{c}$ \\
\hline
\end{tabular}

${ }^{y}$ Fungal dry weight (milligrams) in liquid shake culture was measured at 8 (M. poae and G. incrustans) or 10 (L. korrae) days after inoculation. Colony radius on minimal salts medium was measured every $48 \mathrm{~h}$ from 2 to 6 (M. poae and G. incrustans) or 2 to 14 (L. korrae) days after inoculation.

${ }^{\mathrm{z}}$ Means within a column followed by the same letter are not significantly different $(P<0.05$, least squares means). Each mean represents the average of two isolates of each fungal species for two experiments.

and L. korrae occurred at osmotic potentials of approximately -2.5 to $-3.0 \mathrm{MPa}$ at the highest temperatures tested $\left(35\right.$ and $30^{\circ} \mathrm{C}$, respectively) (Figs. 2 and 4). Furthermore, between osmotic potentials of -2.0 and $-5.0 \mathrm{MPa}, M$. poae grew best at $35^{\circ} \mathrm{C}$. Alternatively, the growth of $G$. incrustans at $35^{\circ} \mathrm{C}$ continued to decline with decreasing osmotic potential (Fig. 3). In comparison, growth of all three fungi on $\mathrm{MgCl}_{2-}$ amended medium was poor.

\section{DISCUSSION}

The solute used to regulate osmotic potential in liquid shake culture had a significant impact on fungal dry weight. Although the growth of all three fungi on minimal salts medium amended with $\mathrm{KCl}$ or PEG did not differ from growth on nonamended medium, dry weights increased 11 to $63 \%$ when grown on medium amended with $\mathrm{MgCl}_{2}$. In a similar study, Brownell and Schneider (3) found that osmoregulant affected the growth of $F$. oxysporum on a basal medium amended with either $\mathrm{MgCl}_{2}$ or $\mathrm{KCl}$. Others have hypothesized that the growth response of ectotrophic root-infecting fungi, such as G. graminis var. avenae, G. graminis var. graminis, and G. graminis var. tritici $(4,25)$, and unrelated fungi, including F. culmorum (6) and Phytophthora spp. (22), to medium osmotically adjusted with salts is a function of water potential $(4,6)$ or osmotic potential $(22,25)$ rather than a function of the specific ion utilized as an osmoregulant. These conclusions, however, were based on studies that used only $\mathrm{KCl}, \mathrm{NaCl}$, sucrose, or a mixture of $\mathrm{KCl}$, $\mathrm{NaCl}$, and $\mathrm{Na}_{2} \mathrm{SO}_{4}$ to adjust osmotic potential. The current study provides evidence that osmoregulant should be considered when evaluating the impact of osmotic potential on fungal growth.

The growth response of $M$. poae and $L$. korrae on nonamended minimal salts medium was similar when evaluated in liquid shake culture and on solid-agar medium.
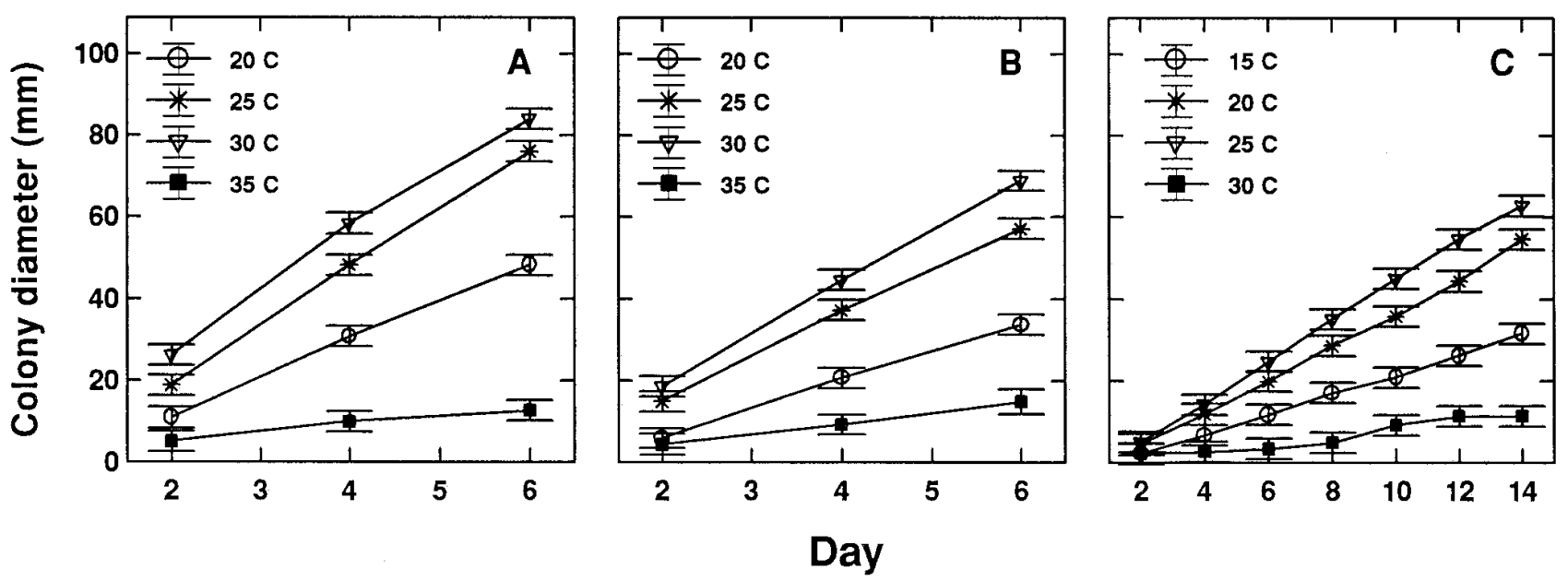

Fig. 1. Mean colony diameter ( \pm standard error) for two isolates each of (A) Magnaporthe poae, (B) Gaeumannomyces incrustans, and (C) Leptosphaeria korrae grown for 6 (G. incrustans and M. poae) or 14 (L. korrae) days on nonamended minimal salts agar medium (-0.12 MPa) at four temperatures. Each data point represents the mean of two experiments for each isolate. 
Even though liquid culture experiments were performed at a temperature that was suboptimal $\left(25^{\circ} \mathrm{C}\right)$ for growth of $M$. poae, the average growth rate of this fungus was greater than the average growth rate of $L$. korrae. On the minimal salts solid-agar medium $(-0.12 \mathrm{MPa})$, the average growth rate of $M$. poae and $G$. incrustans at the optimal temperature of $30^{\circ} \mathrm{C}$ was 7 and 5.7 $\mathrm{mm} /$ day, respectively. These rates are 20 and $27 \%$ less than those reported by Landschoot and Jackson (16) (8.8 and $7.8 \mathrm{~mm} /$ day for $M$. poae and G. incrustans, respectively) who used a more nutrient-rich growth medium containing half-strength PDA $(-0.3$ $\mathrm{MPa})$ at $30^{\circ} \mathrm{C}$. The average growth rate of $G$. incrustans was greater than the average growth rate of $L$. korrae on solid minimal salts medium $(-0.12 \mathrm{MPa})$ but was similar when evaluated in liquid shake culture.
In the current study, the relationship between fungal growth and osmotic potential on solid mineral salts medium was linear or curvilinear. At most of the temperatures tested, mean colony diameter was greatest at the highest amended osmotic potential $(-0.5 \mathrm{MPa})$ and declined with decreasing osmotic potential. The relationship between growth and osmotic potential depended on both osmoregulant and temperature. As osmotic potential decreased (from -1.0 to $-5.0 \mathrm{MPa}), \mathrm{MgCl}_{2}$ was more inhibitory to the growth of $M$. poae and $G$. incrustans than $\mathrm{KCl}$ at varying temperatures. In a similar study, Brownell and Schneider (3) reported that the growth of $F$. oxysporum was inhibited at osmotic potentials less than $-2.0 \mathrm{MPa}$ on solid-agar medium amended with $\mathrm{MgCl}_{2}$ compared to solid medium amended with $\mathrm{KCl}$. At relatively low os- motic potentials, $\mathrm{KCl}$ permits fungal growth to continue because potassium ions are absorbed easily by fungal cells and may function as a compatible cytoplasmic osmoticum with low toxicity (8). Because growth was inhibited on medium amended with $\mathrm{MgCl}_{2}$ at osmotic potentials less than -2.0 $\mathrm{MPa}$, Brownell and Schneider (3) theorized that $\mathrm{MgCl}_{2}$ is either not absorbed by hyphal cells or accumulates to toxic concentrations at low osmotic potentials. In the current study, the inhibitory effect of $\mathrm{MgCl}_{2}$ was even more pronounced for $M$. poae and $G$. incrustans when they were maintained at a temperature that was least optimal $\left(35^{\circ} \mathrm{C}\right)$ for growth.

When $\mathrm{KCl}$ was used as the osmoregulant and temperatures were optimal or nearly optimal $\left(25\right.$ to $30^{\circ} \mathrm{C}$ ) for growth of $M$. poae, colony diameter was greatest at the

\section{Magnaporthe poae}

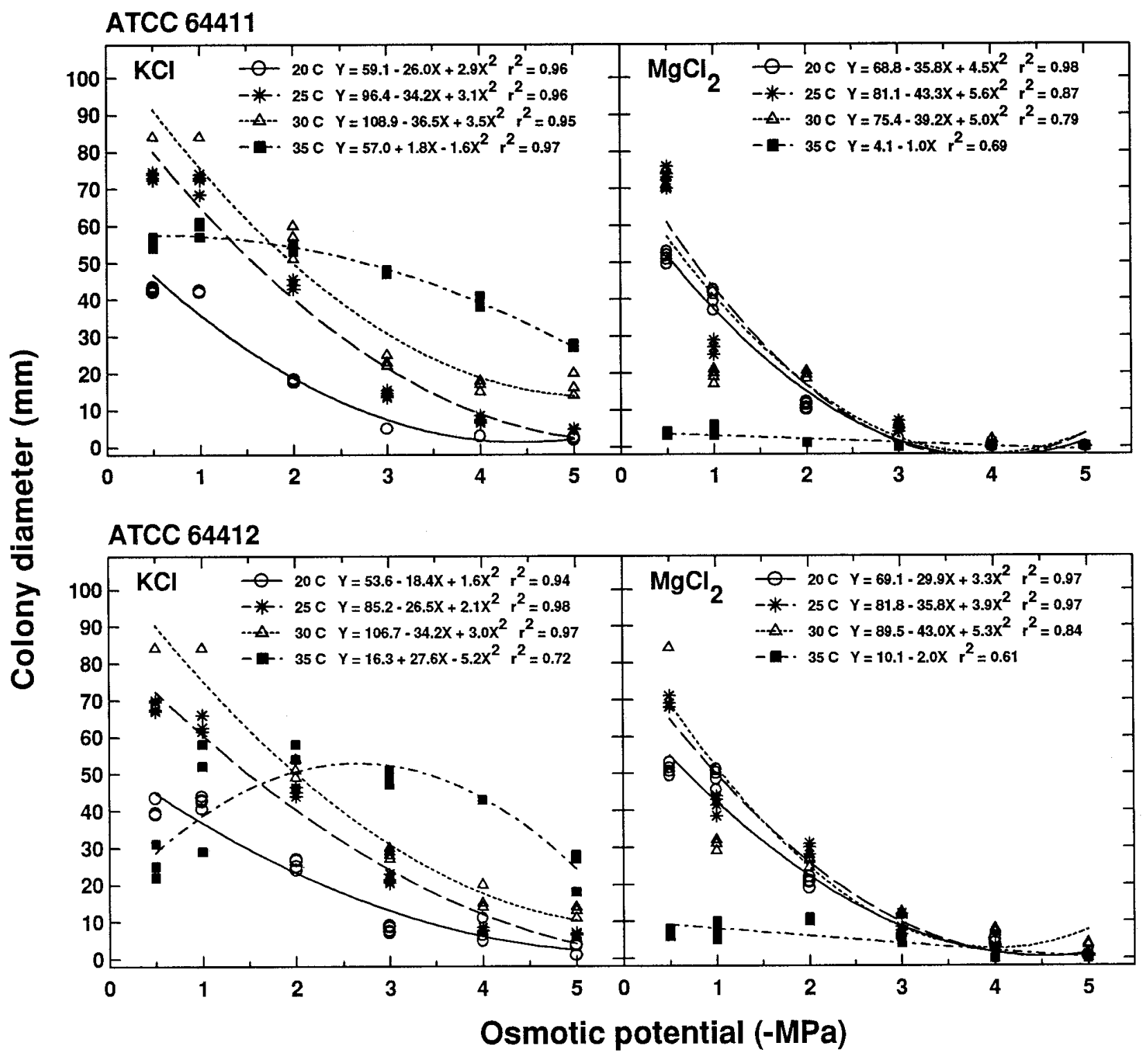

Fig. 2. Impact of osmotic potential on fungal growth of Magnaporthe poae (isolates ATCC 64411 and 64412 ) grown for 6 days at 20 , 25, 30, and $35^{\circ} \mathrm{C}$ on minimal salts agar medium amended with $\mathrm{MgCl}_{2}$ or $\mathrm{KCl}$. Each data point represents the mean of two experiments, and all regression relationships are significant at $P<0.01$. 
highest osmotic potential $(-0.5 \mathrm{MPa})$ and was reduced approximately $50 \%$ at an osmotic potential of $-2.5 \mathrm{MPa}$. Using the same basal salts medium at 25 and $30^{\circ} \mathrm{C}$, Kackley et al. (9) determined that maximal growth of their $M$. poae isolates occurred between -0.12 and $-0.35 \mathrm{MPa}$ and was reduced $50 \%$ at osmotic potentials of -1.03 and $-1.5 \mathrm{MPa}$. It is not unusual for isolates within a species to vary in tolerance to extremes in temperature and osmotic potential (21). Therefore, this disparity could be attributed simply to physiological differences among isolates of $M$. poae.

At temperatures that are supraoptimal for growth of $M$. poae and L. korrae (35 and $30^{\circ} \mathrm{C}$, respectively), maximal growth of both species on medium amended with $\mathrm{KCl}$ was observed at -2.5 to $-3.0 \mathrm{MPa}$ (Figs. 2 through 4 ). The relationship between growth and osmotic potential was curvilinear and represented a significant shift in the osmotic optima for these two pathogens. A similar shift was not observed for $G$. incrustans at $35^{\circ} \mathrm{C}$. These results are consistent with previous studies that investigated the impact of temperature and osmotic potential on the growth of ectotrophic fungi $(9,25)$; however, this is the first report of such a phenomenon for L. korrae.

Cook and Christen (4) working with $G$. graminis var. tritici and two species of $\mathrm{Fu}$ sarium demonstrated that progressively drier conditions (i.e., lower water potentials) were required for maximal growth of these pathogens when the incubation temperature was raised from 10 to $35^{\circ} \mathrm{C}$. This response was presumed to be an adaptive mechanism by these fungi in response to high temperature and low moisture conditions, which often occur during summer, when soil surface temperatures may exceed $35^{\circ} \mathrm{C}$. Wong (25) observed a similar adaptation for $G$. graminis var. avenae, G. graminis var. graminis, and G. graminis var. tritici. The shift in maximal growth of $M$. poae and L. korrae as substrates become drier may enhance the survival of these fungi when temperatures approach their upper limit for growth.

Growth responses recorded for M. poae, G. incrustans, and L. korrae in the current study appear to match their ecological adaptation in nature. L. korrae is capable of growth at higher temperatures and lower water potentials than its Kentucky bluegrass host (21). This supports the observation that necrotic ring spot occurs in the field over a wide range of environmental conditions and that foliar symptoms often

\section{Gaeumannomyces incrustans}

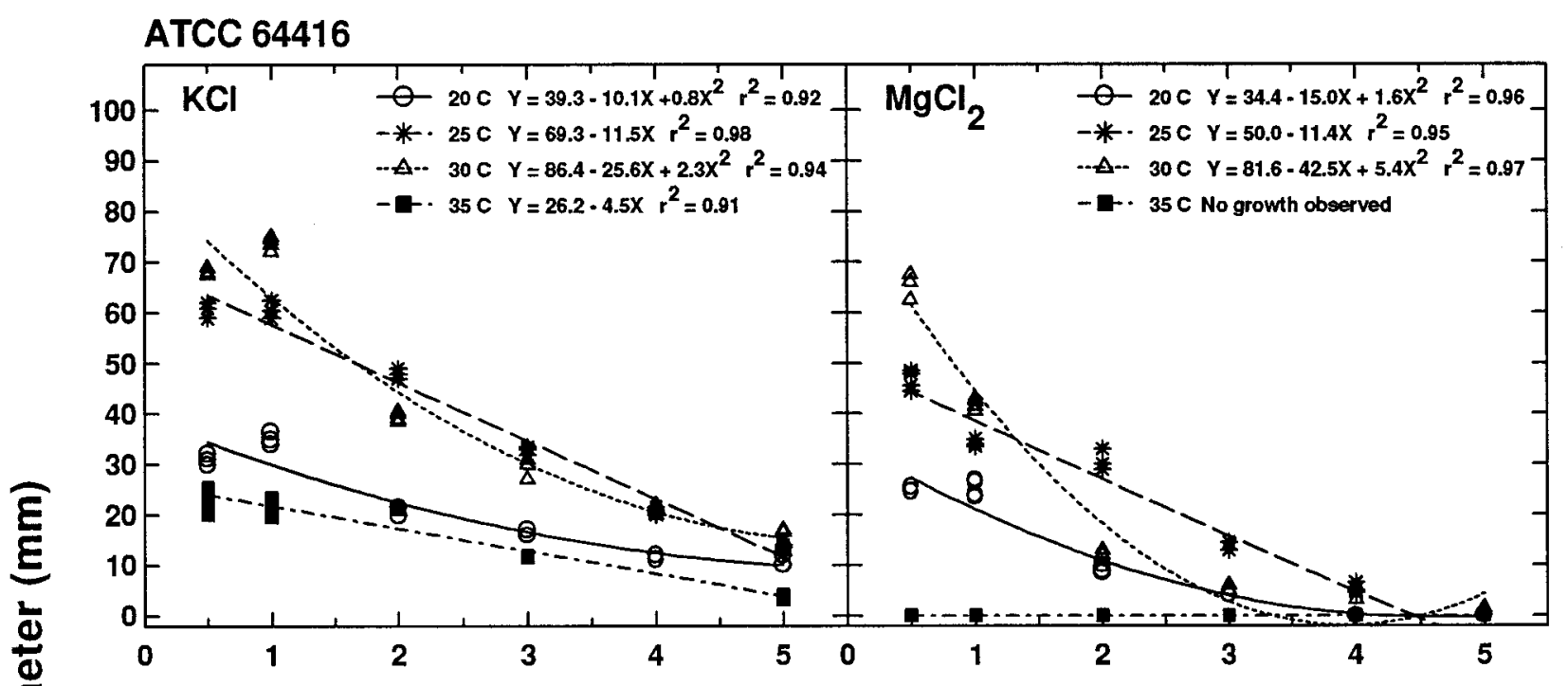

ATCC 64417

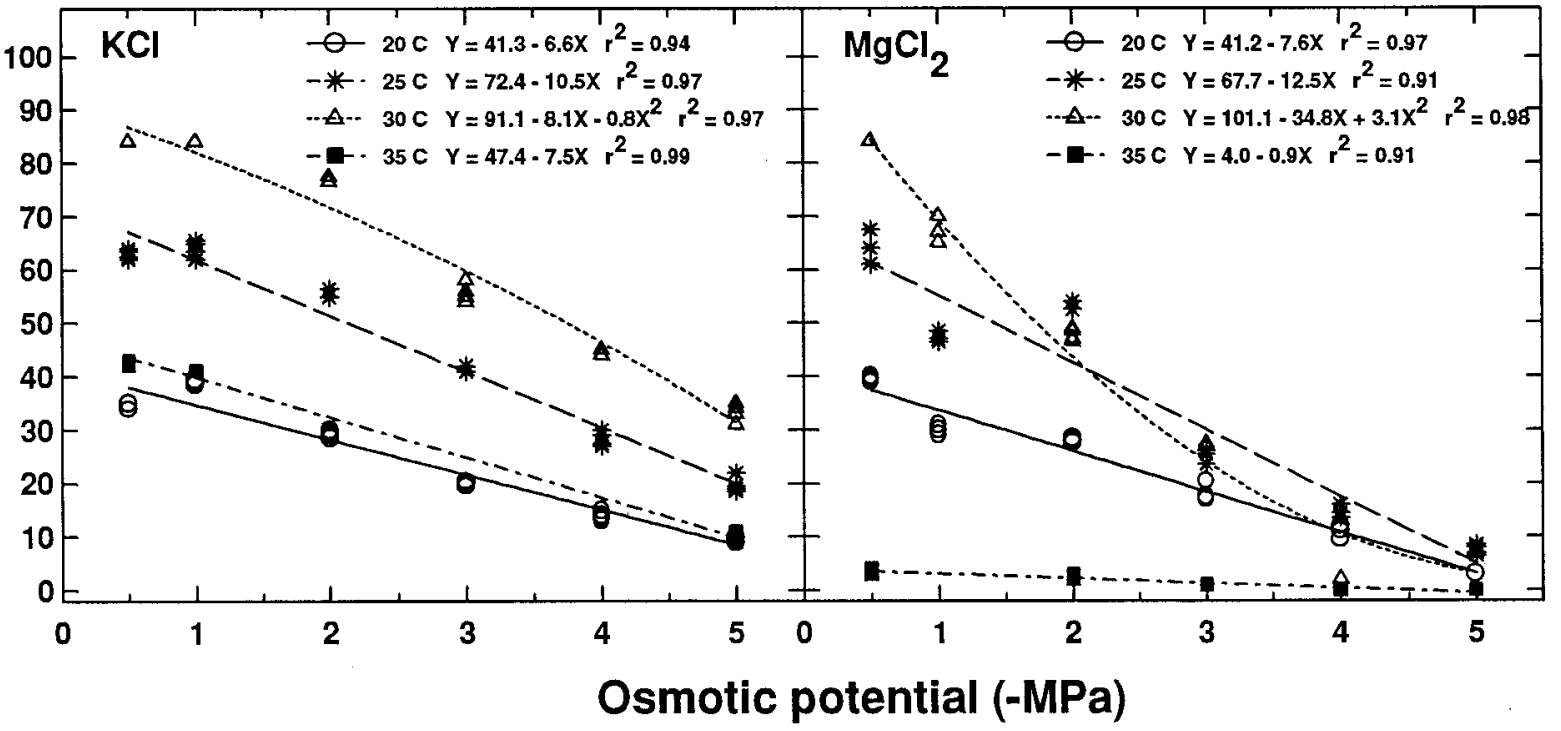

Fig. 3. Impact of osmotic potential on fungal growth of Gaeumannomyces incrustans (isolates ATCC 64416 and 64417) grown for 6 days at 20, 25, 30, and $35^{\circ} \mathrm{C}$ on minimal salts agar medium amended with $\mathrm{MgCl}_{2}$ or $\mathrm{KCl}$. Each data point represents the mean of two experiments, and all regression relationships are significant at $P<0.01$. 
are intensified by drought $(21,26)$. For example, the growth of $L$. korrae in vitro on medium amended with $\mathrm{KCl}$ was not reduced by $50 \%$ until the osmotic potential approached -3.0 and $-3.5 \mathrm{MPa}$ at 20 and $25^{\circ} \mathrm{C}$, respectively.

Summer patch, caused by $M$. poae, is most severe in the field during hot (30 to $35^{\circ} \mathrm{C}$ ), wet weather or when high temperatures are followed by periods of heavy rainfall (20). In vitro $M$. poae grew best at $30^{\circ} \mathrm{C}$ on nonamended and $\mathrm{KCl}$-amended minimal salts agar medium. Moreover, at this temperature on basal medium amended with either $\mathrm{KCl}$ or $\mathrm{MgCl}_{2}$, optimum colony diameter was observed at $-0.5 \mathrm{MPa}$ and decreased with a decrease in osmotic potential. Because the growth of Kentucky bluegrass roots is limited by temperatures between 20 and $25^{\circ} \mathrm{C}$ and essentially stops at temperatures higher than $26^{\circ} \mathrm{C}(1)$, high soil temperatures could provide $M$. poae with a competitive advantage over this host (21). Because M. poae and L. korrae have the ability to grow at low water potentials (less than -2.0 MPa) and supraoptimal temperatures ( 35 and $30^{\circ} \mathrm{C}$, respectively), this advantage may be enhanced further when turf is subjected to moderate drought stress. This is supported by the observation that M. poae grew best between -2.5 and -3.0 $\mathrm{MPa}$ at $35^{\circ} \mathrm{C}$ on medium amended with $\mathrm{KCl}$. In cooler (less than $20^{\circ} \mathrm{C}$ ), moist soils, however, the host often is favored, and summer patch development is often minimal or nonexistent (21). Between 20 and $25^{\circ} \mathrm{C}$, however, symptoms of this disease usually are more severe on turf subjected to moderate drought stress (-0.4 MPa) (10, 11,18).
During periods of drought stress, plants are capable of drawing water from deep in the soil profile, whereas ectotrophic pathogens often are exposed to restrictive water potentials near the soil surface, where evapotranspiration is high (5). As a result, these fungi must be able to adjust to a drier soil environment. Griffin (7) suggested that although soil water potential may not directly affect the population of a pathogen, it may adversely affect the host's ability to prevent infection. Therefore, as the environment becomes unfavorable for growth of the host, various physiological processes, such as disease resistance, may be impaired (5). This could significantly reduce the degree of host resistance and, thus, enhance disease development.

Although G. incrustans has been isolated from the roots of plants exhibiting

\section{Leptosphaeria korrae}

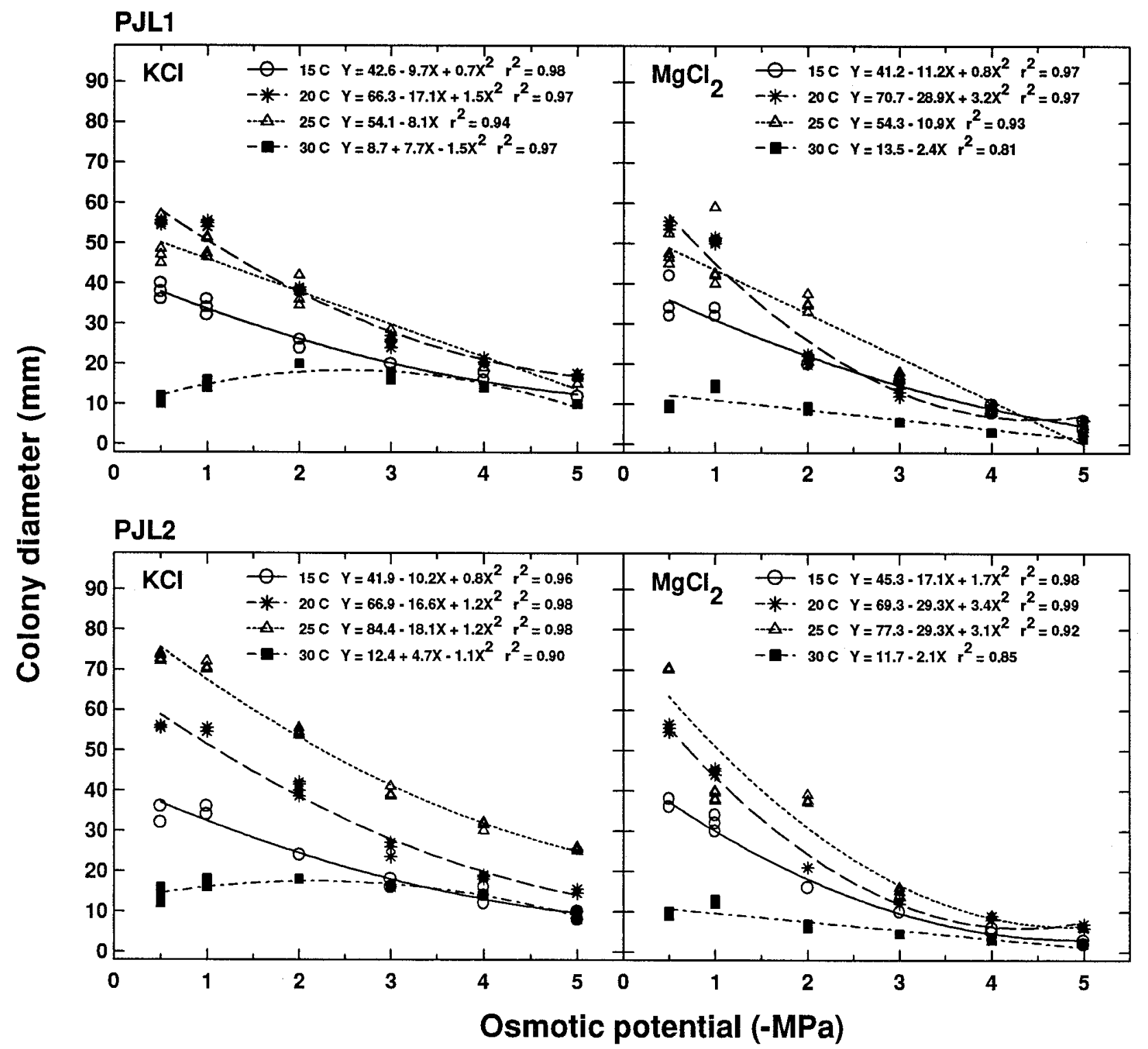

Fig. 4. Impact of osmotic potential on fungal growth of Leptosphaeria korrae (isolates PJL1 and PJL2) grown for 14 days at $15,20,25$, and $30^{\circ} \mathrm{C}$ on minimal salts agar medium amended with $\mathrm{MgCl}_{2}$ or $\mathrm{KCl}$. Each data point represents the mean of two experiments, and all regression relationships are significant at $P<0.01$. 
foliar symptoms of summer patch (16), a proven association between $G$. incrustans and this disease has not been established. Pathogenicity has been confirmed in the growth chamber with Poa annua (16) and in growth-chamber and field trails with selected species and cultivars of fine fescues (12); however, G. incrustans does not appear to be as pathogenic to turf as $M$. poae $(12,13)$.

It is apparent that temperature plays an important role in the growth of fungi. Most of the initial work describing temperatures optimal for the growth of ectotrophic rootinfecting fungi $(16,21)$ was conducted on nonamended nutrient agar at an osmotic potential of approximately $-0.3 \mathrm{MPa}$. White et al. (24), assessing the relationship between leaf water potential and soil moisture for three tall fescue selections, found that the water potential of leaf tissue ranged from -0.6 to $-3.0 \mathrm{MPa}$ depending on the degree of soil moisture stress. Papendick and Cook (17) found a similar range of water potential ( -2.0 to $-3.5 \mathrm{MPa})$ within the leaves and roots of mature wheat tissue. Although the temperature optima reported for the growth of ectotrophic fungi on nonamended media at high osmotic potentials adds to our general understanding of these fungi, it may not accurately reflect their growth over the full range of water potentials encountered during the host-pathogen process $(4,25)$. Therefore, to adequately evaluate the impact of temperature and osmotic potential on the growth of ectotrophic pathogens of turf, studies must continue to investigate these factors, both independently and interactively. Moreover, it is apparent that the osmoregulant must be considered when evaluating the effect of osmotic potential on fungal growth.

\section{ACKNOWLEDGMENTS}

We thank P. J. Landschoot for advice and fungal isolates and K. Kackley-Dutt, P. Majumdar, and M. Karasik for technical assistance.

\section{LITERATURE CITED}

1. Beard, J. B. 1973. Turfgrass: Science and Culture. Prentice-Hall, Englewood Cliffs, NJ.

2. Brown, R. W., and Collins, J. M. 1980. A screen-caged thermocouple psychrometer and calibration chamber for measurements of plant and soil water potential. Agron. J. 72:851-854.

3. Brownell, K. H., and Schneider, R. W. 1985. Roles of matric and osmotic components of water potential and their interaction with temperature in the growth of Fusarium oxysporum in synthetic media and soil. Phytopathology 75:53-57.

4. Cook, R. J., and Christen, A. A. 1976. Growth of cereal root-rot fungi as affected by temperature-water potential interactions. Phytopathology 66:193-197.

5. Cook, R. J., and Papendick, R. I. 1972. Influence of water potential of soils and plants on root disease. Annu. Rev. Phytopathol. 10: 349-374.

6. Cook, R. J., Papendick, R. I., and Griffin, D. M. 1972. Growth of two root-rot fungi as affected by osmotic and matric water potentials. Soil Sci. Soc. Am. Proc. 36:78-82.

7. Griffin, D. M. 1969. Soil water in the ecology of fungi. Annu. Rev. Phytopathol. 7:289-310.

8. Harris, R. F. 1981. Effect of water potential on microbial growth and activity. Pages 23-95 in: Water Potential Relations in Soil Microbiology. J. F. Parr, W. R. Gardner, and L. F. Elliott, eds. Soil Sci. Soc. Am. Special Publ. 9. Soil Science Society of America, Madison, WI.

9. Kackley, K. E., Grybauskas, A. P., and Dernoeden, P. H. 1990. Growth of Magnaporthe poae and Gaeumannomyces incrustans as affected by temperature-osmotic potential interactions. Phytopathology 80:646-650.

10. Kackley, K. E., Grybauskas, A. P., Dernoeden, P. H., and Hill, R. L. 1990. Role of drought stress in the development of summer patch in field-inoculated Kentucky bluegrass. Phytopathology 80:655-658.

11. Kackley, K. E., Grybauskas, A. P., Hill, R. L., and Dernoeden, P. H. 1990. Influence of temperature-soil water status interactions on the development of summer patch in Poa spp. Phytopathology 80:650-655.

12. Kemp, M. L. 1991. The susceptibility of fine fescues to isolates of Magnaporthe poae and Gaeumannomyces incrustans. Ph.D. dissertation. Rutgers University, New Brunswick, NJ.

13. Landschoot, P. J., Gould, A. B., and Clarke, B. B. 1993. Ecology and epidemiology of ectotrophic root-infecting fungi associated with patch diseases of turfgrasses. Pages 73-105 in: Turfgrass Patch Diseases Caused by Ectotrophic Root-Infecting Fungi. B. B. Clarke and A. B. Gould, eds. The American Phytopathological Society, St. Paul, MN.

14. Landschoot, P. J., and Jackson, N. 1989 Gaeumannomyces incrustans sp. nov., a rootinfecting hyphopodiate fungus from grass roots in the United States. Mycol. Res. 93:55-58.

15. Landschoot, P. J., and Jackson, N. 1989. Magnaporthe poae sp. nov., a hyphopodiate fungus with a Phialophora anamorph from grass roots in the United States. Mycol. Res. 93:5962.

16. Landschoot, P. J., and Jackson, N. 1990. Pathogenicity of some ectotrophic fungi with Phialophora anamorphs that infect the roots of turfgrasses. Phytopathology 80:520-526.

17. Papendick, R. I., and Cook, R. J. 1974. Plant water stress and development of Fusarium foot rot in wheat subjected to different cultural practices. Phytopathology 64:358-363.

18. Smiley, R. W. 1987. The etiologic dilemma concerning patch diseases of bluegrass turfs. Plant Dis. 71:774-781.

19. Smiley, R. W., and Craven Fowler, M. 1984. Leptosphaeria korrae and Phialophora graminicola associated with Fusarium blight syndrome of Poa pratensis in New York. Plant Dis. 68:440-442.

20. Smiley, R. W., Dernoeden, P. H., and Clarke, B. B. 1992. Compendium of Turfgrass Diseases. 2nd ed. The American Phytopathological Society, St. Paul, MN

21. Smiley, R. W., Fowler, M. C., and Kane, R. T. 1985. Temperature and osmotic potential effects of Phialophora graminicola and other fungi associated with patch diseases of $\mathrm{Poa}$ pratensis. Phytopathology 75:1160-1167.

22. Sommers, L. E., Harris, R. F., Dalton, F. N., and Gardner, W. R. 1970. Water potential relations of three root-infecting Phytophthora species. Phytopathology 60:932-934.

23. Walker, J., and Smith, A. M. 1972. Leptosphaeria narmari and $L$. korrae spp. nov., two long-spored pathogens of grasses in Australia. Trans. Br. Mycol. Soc. 58:459-466.

24. White, R. H., Engelke, M. C., Morton, S. J., and Ruemmele, B. A. 1992. Competitive turgor maintenance in tall fescue. Crop Sci. 32: 251-256.

25. Wong, P. T. W. 1983. Effect of osmotic potential on the growth of Gaeumannomyces graminis and Phialophora spp. Ann. Appl. Biol. 102:67-78.

26. Worf, G. L., Stewart, J. S., and Avenius, R. C. 1986. Necrotic ring spot disease of turfgrass in Wisconsin. Plant Dis. 70:453-458. 